Journal of Environmental Law 22:2 C The Author [2010]. Published by Oxford University Press. All rights reserved. For Permissions, please email: journals.permissions@oxfordjournals.org doi:10.1093/jel/eqq003 Advance Access published on 11 March 2010

\title{
European River Basin Districts: Are They Swimming in the Same Implementation Pool?
}

\author{
Andrea M. Keessen, ${ }^{*}$ Jasper J.H. van Kempen, ${ }^{\dagger}$ \\ Marleen van Rijswick, ${ }^{*}$ Jan Robbe ${ }^{\S}$ and \\ Chris W. Backes**
}

\begin{abstract}
This article presents a comparative perspective of the implementation of the Water Framework Directive (WFD). The investigated Member States are the Netherlands, Luxembourg, Belgium, France, Germany, the United Kingdom, Denmark, Romania, Italy, Spain and Portugal. The implementation of the WFD in these Member States was researched with the help of legal experts who completed questionnaires or were interviewed and-limited to five Member States-through interviews with civil servants who were involved with the implemention of the WFD. This research demonstrates that the WFD leaves so much room for discretion that the Member States adopt different approaches concerning the implementation of fundamental parts of the Directive. Although the need for flexibility due to the differences in circumstances is recognised, the new governance approach of the WFD demonstrates a risk that unambitious national practices will lead
\end{abstract}

* Assistant Professor, Institute of Constitutional and Administrative Law, Utrecht University, The Netherlands (a.m.keessen@uu.nl)

$\dagger$ PhD Candidate, Utrecht University

* Professor of European and Dutch Water Law, Utrecht University

$\S$ Associate Professor, Utrecht University

** Professor of Administrative Law, Maastricht University 
to a lack of practical effectiveness. Especially in transboundary river basins this may harm more ambitious Member States.

Keywords: Water Framework Directive, implementation, comparative study, environmental objectives, discretion

\section{Introduction}

The Water Framework Directive (WFD) is the new European framework directive on water management based on a river basin approach. ${ }^{1}$ The WFD can be characterised by more room for flexibility and it leaves greater room for policy discretion by the Member States concerning goal setting for ecological objectives, the designation of water bodies, the use of exemptions and the way the concept of no deterioration is given shape. The WFD contains mostly procedural obligations. Legislation is enacted at several levels-for example the EC level, the national level and the river basin level. Measures should also be taken at several levels and in several policy fields, for example to reduce the use of fertilizer and manure and regarding products to diminish pollution by diffuse sources. There is more attention to participation in all phases of the implementation process. With these characteristics the WFD is an example of the approach towards more new governance in EC environmental law. ${ }^{2}$ This article is based on a research project which focuses on the question whether the discretion that is given to the Member States with regard to implementation leads to differences in implementation as far as some basic and crucial elements of the WFD are concerned. Our hypothesis is that too many differences will make it more difficult to create a level playing field and to succeed in an integrated approach for the management of-often-transboundary river basins.

The WFD sets out the aim of achieving a good status for European waters. The Member States should accomplish this by 2015 through the river basin management approach. Some may say that this is too ambitious, even though European regulation on water quality has existed since the $1970 \mathrm{~s}^{3}$ and the WFD only adds the ecological protection of the aquatic environment. Yet this

1 Council Directive (EC) 2000/60 establishing a framework for Community action in the field of water policy [2000] OJ L 327/1.

2 See amongst others: M Lee, 'Law and Governance of Water Protection Policy' in J Scott (ed), Environmental Protection. European Law and Governance (OUP, Oxford 2009); W Howarth, Aspirations and Realities under the Water Framework Directive: Proceduralisation, Participation and Practicalities' (2009) 2 JEL 391-417; J Scott, 'Flexibility, Proceduralization and Environmental Governance in the EU' in G de Burca and J Scott (eds), Constitutional Change in the EU. From Uniformity to Flexibility? (Hart Publishing, Oxford and Portland, Oregon 2000); HFMW Van Rijswick, Moving Water and the Law, On the Distribution of Water Rights and Water Duties within River Basins in European and Dutch Water Law (Europa Law Publishing, Groningen 2008).

3 Eg Directive (EEC) 76/464 [1976] OJ L129/23; replaced by Directive (EC) 2006/11 [2006] OJ L $64 / 52$. 
negative assumption may be correct, as the 2007 Commission report on the implementation of the WFD revealed that many waters are at risk of not being able to meet the 2015 deadline. ${ }^{4}$ This has raised the question of how the Member States are progressing with implementing the WFD. Are there any front runners or is everyone lagging behind? ${ }^{5}$ This simple question has raised further questions, in particular: what exactly is the WFD asking Member States to do about water quality? How much room for discretion do the Member States have in the implementation process? This article explores these questions as it offers an analysis of the legal obligations following from the WFD in so far as they are implemented in the national law of several Member States. Not all aspects of the implementation are compared-only the legal implementation of ambitions and objectives, and in particular the way norms and standards set by the EC and the Member States are legally formulated and regulated in national law, the way in which exemptions are regulated and the legal meaning of the no deterioration principle in the national law of the Member States. Finally, the integration of water objectives in decision making in the field of water management and other policy fields is analysed.

In order to understand how various Member States are implementing the WFD, its legal implementation was investigated in eleven of them: the Netherlands, Luxembourg, Belgium (Flanders and Wallonia), France, Germany (North Rhine-Westphalia and Baden-Wurttemberg), the United Kingdom (England and Wales), Denmark, Romania, Italy, Spain and Portugal. ${ }^{6}$ of course this would not have been possible without the help of legal experts who were willing to answer questions about the implementation of the WFD in their Member State. These questionnaires were completed between August 2008 and August 2009. ${ }^{7}$ In addition, in a combined effort by legal and political

4 Communication from the Commission to the European Parliament and the Council, "Towards sustainable water management in the European Union - First stage in the implementation of the Water Framework Directive' 2000/60/EC, COM (2007) 128 final. See also: Commission (EC) 'Report to the European Parliament and the Council in accordance with article 18.3 of the Water Framework Directive 2000/60/EC on programmes for monitoring of water status' COM (09) 156 final, 1 April 2009.

5 See on leaders and laggards: TA Borzel, 'Why There is No 'Southern Problem'. On Environmental Leaders and Laggards in the European Union' (2000) 7 JEPP 141-62.

6 Note that the implementation of the WFD may differ from state to state or from region to region, depending on the division of competence within a Member State. This applies in particular to those Member States where the investigated region is mentioned in brackets.

7 Respectively: AM Keessen, JJM van Kempen, J Robbe and HFMW Van Rijswick (the Netherlands), F Rosen (Luxembourg), I Larmuseau (Flanders, Belgium), L Renoy, C Born and F Haumont, P De Smedt (Wallonia and Flanders, Belgium); B Drobenko, T Van Dinh and E Guyard (France); R Wergen, K Gütling, F Jörrens, A Hoppmann, C Backes, C von Kries and G Winter (North Rhine-Westphalia and Baden-Wurttemberg, Germany); S Hendry (England \& Wales, United Kingdom); P Pagh (Denmark); V Marcusohn (Romania); D Amirante and C Petteruti (Italy); F López Ramón (Spain) and A de Sousa Aragao (Portugal). The authors are grateful for their cooperation. Most country reports were presented at the 2009 conference of the European water law network ('le réseau Européen du droit de l'eau') in Bucharest, Romania. All questionnaires are on file with the authors. 
science researchers, five of these Member States were selected for an in-depth investigation into the implementation of the WFD in a specific river basin district on the basis of interviews with civil servants working for the competent authorities held in 2008, before the completion of the river basin management plans. ${ }^{8}$ The following sub-river basin districts were selected: the Dommel, within the Meuse river basin district in the Netherlands; the Wensum within the Anglia and Wensum catchment in England in the United Kingdom; the Ruhr catchment in the Meuse river basin district in North Rhine-Westphalia in Germany; St Brieuc within the Loire-Brittany river basin district and its sub-basin the Baie de St Brieuc in France; and the sub-basin Odense Fjord Basin in Jutland and Funen in Denmark. It will be seen below that there are rather significant differences between the investigated Member States regarding their ambitions and the legal meaning they give to the obligations following from the WFD.

\section{The Aim of the WFD}

The ultimate aim of the WFD is that the European surface waters achieve 'good chemical and ecological status' and the European ground waters achieve 'good chemical and quantitative status.' This requires meeting environmental objectives. These consist, on the one hand, of ecological objectives, such as salinity, transparency, the presence of aquatic flora and fauna and, on the other hand, of chemical objectives, such as a maximum concentration of dangerous substances in water bodies. The chemical objectives are set at EU level, while the ecological objectives, including the objectives for substances that influence the ecological status-comparable with the formal list II substances of Directive 2006/11/EC - are set by the Member States. ${ }^{10}$ The Member States have to elaborate the environmental objectives for their water bodies in river basin management plans (RBMP), while the measures to attain these objectives have to be established by the Programme of Measures (PoM). Even though the WFD prescribes that all waters in European river basins should meet these objectives in order to achieve good status, the WFD allows the Member States to invoke one or more exemptions in their national RBMPs. This may occur for instance if the timely achievement of good ecological status is impossible in a particular water body. The available exemptions

8 This resulted in: Y Uitenboogaart, JJH van Kempen, M Wiering and HFMW Van Rijswick (eds), Dealing with Complexity and Policy Discretion, A Comparison of the Implementation of the Water Framework Directive in Five Member States (Sdu uitgevers, The Hague 2009). See: <http:// www.sdu.nl $>$ accessed 20 January 2010. Transcripts of the interviews are on file with the authors.

9 Arts 1 and 4 WFD. The good quantitative status of groundwater refers to the level of groundwater and not to its quality. It is not further elaborated upon in this article.

10 Directive (EC) 2006/11 on pollution caused by certain dangerous substances discharged into the acquatic environment of the Community [2006] OJ L 64/52. See Section 3. 
under the WFD consist of an extension of the deadlines from 2015 up to 2027, achieving less stringent environmental objectives, and a temporary deterioration or deterioration caused by new developments. These exemptions are narrowly circumscribed and can therefore only be invoked if a number of conditions are met. ${ }^{11}$

Both the presence of ecological goals and exemptions created uncertainty among the Member States about the status of the objectives, even of those objectives that were translated into environmental quality standards and thus specifically set at EU level. Indeed, the WFD allows Member States a considerable degree of freedom in both the process and outcome of implementation. ${ }^{12}$ However, it compels Member States to act within the boundaries of pre-existing water directives and other relevant European legislation, in particular those pieces of legislation concerning nature conservation, agricultural sources and so on. In addition, in order to meet the obligations set in the new Directives - the WFD, the Dangerous Substances Directive, the Groundwater Directive and the Priority Substances Directive ${ }^{13}$ - the Member States must at least take the so-called 'basic measures' before 2015. These basic measures stem mainly from the pre-existing European water-related directives, such as the Urban Waste Water Directive, the Birds and Habitats Directives, the Bathing Water Directive, the Nitrates Directive and the Directive on Integrated Pollution Prevention and Control (IPPC). ${ }^{14}$ Even though the Member States were already obliged to comply with chemical water objectives emanating from these 'old' Directives, that is a daunting prospect, because the WFD integrated them, added ecological objectives and included a strict time frame, albeit leaving open the option of an extension.

In order to attain the aim of good chemical and good ecological status, specific objectives have to be met. Continuing a long tradition in European water law, the chemical objectives are set at the EU level, in the Annexes to the WFD or in its daughter Directives. These objectives concern substances and are set with the aim of protecting the environment and the health of human beings. These objectives in themselves do not leave Member States with much room for discretion, but their legal use may differ as will be seen below. By contrast, some ecological objectives, such as the presence of fish, are new and are usually not clearly prescribed by the WFD or one of its daughter directives. Those

11 Art 4 WFD.

12 Milieu en Natuur Planbureau, Welke ruimte biedt de Kaderrichtlijn Water? Een Quick Scan (How Much Room Does the WFD leave? A Quick Scan) (MNP, Bilthoven [2006]).

13 Respectively Water Framework Directive 2000/60; Directive (EC) 2006/11 on pollution caused by certain dangerous substances discharged in the aquatic environment of the Community (Dangerous Substances Directive) [2006] OJ L 64/52; Directive (EC) 2006/118 on the protection of groundwater against pollution and deterioration (Groundwater Directive) [2006] OJ L 372/19; and Directive (EC) 2008/105 on environmental quality standards in the field of water policy (Priority Substances Directive) [2008] OJ L 348/84.

14 See for an overview of these Directives: JH Jans, European Environmental Law (3rd rev edn Europa Law Publishing, Groningen 2008). 
ecological objectives which would constitute chemical objectives, except that they are specifically determined for the protection of flora and fauna, could be set at the EU level. Setting other ecological objectives at the EU level, such as morphology or the desired presence of a certain fish, would be near to impossible, since they differ for each type of water body as they depend on local circumstances.

The WFD generally leaves it to the Member States to set the ecological objectives for their water bodies. This has freed the European legislator from the Herculean task of setting these objectives. ${ }^{15}$ Yet this task is not completely left to the Member States, as the setting of ecological objectives should occur in cooperation with other Member States. This cooperation takes the form of an intercalibration exercise. ${ }^{16}$ Like other Common Implementation Strategies, the intercalibration exercise serves to harmonise the implementation by the Member States, in this case their understanding of 'good ecological status, ${ }^{17}$ The Commission also participates in the process to ensure that the common understanding of the Member States is consistent with the aims and definitions of the Directive. The intercalibration exercise is referred to in the WFD (in Annex V Section 1.4.1) and the results are important in setting the ecological targets for the natural surface water bodies. The results up to this point have resulted in a Commission decision establishing the values of the Member States monitoring classifications. ${ }^{18}$ The process has still not been fully completed and therefore some results will only be ready for the second phase of the RBMPs in 2015 . $^{19}$

\section{Designation of Water Bodies}

Before objectives for water bodies can be set, the Member States need to designate surface water bodies on the basis of their ecological quality. ${ }^{20}$ The three categories are normal (often called natural), heavily modified or artificial water bodies. This designation has important consequences for the overall good status obligation to be achieved. Only natural water bodies have to achieve good ecological status, unless an exemption is justified. Heavily

15 W Howarth, 'The Progression Towards Ecological Quality Standards' (2006) 3 JEL 3-35.

16 Commission Decision (EC) 2005/646 [2005] OJ L243/1.

17 M Lee, 'Law and Governance of Water Protection Policy' in J Scott (ed), Environmental Protection. European Law and Governance (OUP, Oxford 2009).

18 Commission Decision (EC) 2008/915 [2008] OJ L332/20.

19 RWS Waterdienst, EU KRW Internationaal, Relevante Ontwikkelingen in de Internationale Stroomgebieden, Brussel en de Rest van Europa, Achtergronddocument bij Ex Ante Evaluatie KRW (Ministry of Traffic, Public Works and Water Management, Water Agency, EU WFD International, Relevant Developments in Transboundary River basins, Brussels and the Rest of Europe 2008).

20 Guidance document no 2 Identification of Water Bodies (2003) provides assistance to the Member States. 
modified or artificial water bodies only have to achieve good ecological potential. Good ecological potential will be tailored by the Member States to the function of each of these water bodies, which gives them room for discretion. For instance, the good ecological potential of a canal can be achieved without changing the modified hydromorphological characteristics, while that would be necessary for achieving good ecological status. The designation of a water body also influences the setting of certain environmental objectives.

While the ecological objectives for natural water bodies refer to natural conditions to attain good ecological status, the ecological objectives for heavily modified or artificial water bodies that have to be met to attain a good ecological potential lack an obvious state of reference to which to refer. The objectives may be based on the feasibility and cost-effectiveness of measures to improve the ecological potential. This approach is the so-called Prague method (or mitigation measures method) for the setting of ecological objectives for these water bodies. Only some Member States refer to natural conditions in the case of heavily modified or artificial water bodies (the reference-based method). Most Member States use the Prague method for water bodies with a specific function-for example drinking water supply/storage or canalisation for agriculture or flood prevention. If this function prevents good ecological status from being attainable, that might be used as an excuse for simply doing nothing. However, it remains mandatory to take mitigation measures to attain good ecological potential. ${ }^{21}$ Nevertheless, it must be concluded that the more water bodies are designated as heavily modified or artificial, the more room for discretion is left in the implementation of the WFD, unless the European Court of Justice (ECJ) should decide that the Prague method is not in conformity with the WFD.

The differences between Member States become obvious when taking a look at the level of river basin districts. As can be seen in the table below, the investigated river basin districts in the Netherlands, Germany and the United Kingdom occupy the first three places concerning the designation of water bodies as highly modified or artificial. Interestingly, this designation did not take place on the basis of the same criteria. In the investigated river basin district in Denmark, highly modified water bodies were designated as natural when it was considered that it would be possible to achieve good ecological status for that water body (the reference method). It must be mentioned that at the time of the research the RBMPs were only draft plans and the

21 Art 4(1)(a)(iii) WFD2000/60. See: Conclusions of CIS Strategy Workshop Brussels, 12-13 March 2009, on Heavily Modified Water Bodies: Information Exchange on Designation, Assessment of Ecological Potential, Objectives Setting and Measures. Available at: <http:// ecologic-events.eu/hmwb/documents/FinalHMWBConclusions.pdf $>$ accessed 20 January 2010 . 
Table 1. The designation of water bodies in five river basin districts

\begin{tabular}{lccc}
\hline & HMWB (in \%) & AWB (in \%) & Natural (in \%) \\
\hline RBD Meuse in The Netherlands & 92 & 7 & 1 \\
RBD Ruhr in Germany & $60^{\mathrm{a}}$ & $>60^{\mathrm{a}}$ & $<40$ \\
RBD Loire-Brittany in France & 10 & 1.5 & 88.5 \\
RBD Anglia in the United Kingdom & 54 & 15 & 29 \\
BD Jutland and Funen in Denmark & $10^{\mathrm{a}}$ & $10^{\mathrm{a}}$ & 90 \\
\hline
\end{tabular}

The available information about this river basin district does not make it possible to differentiate between highly modified water bodies (HMWB) and artificial water bodies (AWB).

decision-making process concerning designation of water bodies could still be influenced by political arguments. ${ }^{22}$ In the Netherlands, the designation occurred on the basis of the current situation of the water body. The potential of the water body was subsequently investigated when the specific ecological objectives were set for that water body (the Prague method). According to the Dutch interviewees, some of the heavily modified water bodies are not so heavily modified that they cannot attain good ecological status. They were not designated as a natural water body for fear that the standards for achieving good ecological status are so high that it may not be reached, while good ecological potential seems easier to attain. ${ }^{23}$

\section{Setting Environmental Objectives}

Setting environmental objectives for specific water bodies is an enormous task. ${ }^{24}$ For the Netherlands alone three documents, each with a dimension resembling a telephone book, describe the ecological objectives for Dutch waters. These objectives are set at the national level by an Order in Council and are then elaborated by the Provinces, the Inspectorate for Transport, Public Works and Water Management and the Water Boards in the RBMPs and PoMs that apply to each specific water body. In Denmark, the objectives are set by the Ministry of Environment, while the specific objectives for individual water bodies are set by the Environmental Centres which develop the RBMPs, which are subsequently implemented by the municipalities in their municipal action plans. In France, the Environmental Code contains the general objectives, while the RBMP contains the specific objectives for each water body to be implemented in sub-RBMPs. The French division of competence is replicated

22 The research at the level of the river basins was conducted between August and December 2008. Under the WFD 2000/60, the first RBMPs were due by the end of December 2009.

23 Uitenboogaart (n 8), in particular 192-6.

24 W Howarth, Accommodation Without Resolution? Emission controls and Environmental Quality Objectives in the Proposed EC Water Framework Directive' (1999) 1 ELR 3, 6-26. 
in Romania and Italy. In Germany, things are slightly more complicated. The objectives are set at the Federal level, while the Länder are responsible for the elaboration of the objectives in RBMPs, which occurs in consultation with local authorities. In the United Kingdom (England and Wales), the environmental objectives are only elaborated in the RBMPs. At the time of the research, the environmental objectives for the Flemish (Belgium) river basins had not yet been set.

The interviews confirmed that setting environmental objectives, in particular ecological objectives, is not an easy task. During the process of setting the environmental objectives for the Dutch Dommel river basin, there was discussion on how to set ecological goals and goals for related chemical substances for water bodies that are modified or heavily modified. Part of the ecological goal setting is about the chemical conditions of water bodies needed to reach good ecological potential. The problem was that there were certain factors which made it difficult to realise improvements, such as hydromorphological recovery and improvements in streaming. Where improvements are very limited, water bodies cannot even achieve good ecological potential. This raised the question of why one should strive for a high standard for some of the chemical elements for good ecological status-nitrates and phosphorus in particular-that belong to an ideal ecological situation that will not be attained anyway. In the end, it turned out to be so difficult to set a specific standard for these substances that the water board decided to use the national standards for good ecological status, even though they were considered to be too stringent. $^{25}$

In other river basins it is also a complicating factor that the development of the ecological objectives does not match the time frame within which the river basin district plans and programmes of measures have to be developed. ${ }^{26}$ For instance, in the German Ruhr river basin district in North Rhine-Westphalia, the German interviewees said that the authorities are determined to do what they can to improve the ecological quality of heavily modified or artificial water bodies, but they are taking action in the absence of a clear meaning of the objectives that permit the achieving of a good ecological potential for these water bodies. The same situation was reported in the French river basin district Loire-Brittany. ${ }^{27}$ This uncertainty leads to RBMPs and PoMs which are not necessarily based on sound ecological advice.

25 Uitenboogaart and others (n 8).

26 The same problem occurs insofar as the river basin management plan and the programme of measures have to provide for measures to sustain Natura 2000 areas that depend on water, since the Natura 2000 plans and programmes of measures are not synchronous with the WFD plans and programmes of measures. A Keessen and HFMW Van Rijswick, 'Drinkwaterwinning in een Natura 2000 gebied. Het Juridische Regime voor Beschermde Gebieden' (The Abstraction of Drinking Water in Natura 2000 sites, The Legal Regime for Protected Areas) 35 (2008) 9 M en R 557-66. 


\section{Obligation of Result or of Best Efforts?}

It is not easy to determine how the good status obligation and the environmental objectives are qualified by the Member States. These differences may have consequences for the implementation of the WFD. If the good status obligation is an obligation of result, than it has to be attained, unless legitimate use of exemptions is possible. If attaining good status is an obligation of best efforts, that means that besides the exemptions foreseen in the WFD, there can be additional reasons not to comply with the Directive and Member States are not obliged to take additional measures to comply. ${ }^{28}$ The differences between intervention values and target values can seriously affect the possibilities for attaining the necessary objectives in transnational river basins. The main consequence concerns the action to be taken by the authorities when the objectives are not met. If the objectives are considered to be intervention values, then they indicate when the functional properties of the water for humans, plant and animal life are seriously impaired or threatened and they are representative for the level of contamination in cases of serious water contamination. In other words, the objectives indicate when the competent authorities have to intervene in order to prevent damage. However, if the same objectives are seen as target values, they indicate that the functional properties of the water for humans, plant and animal life are sufficiently protected at that level. Moreover, the word target implies that the water quality does not currently meet these values, but that the authorities aim to meet the target values in the (near?) future.

In many investigated Member States, the legal qualification to be given to the good status obligation and to environmental objectives is not really a hot item. For instance in Spain, the law states that the objectives have to be met. From this sentence, the Spanish legal expert deduced that achieving good status is an obligation of result and that the objectives are probably intervention values. Whether this interpretation is correct or not, is the most passionately debated topic concerning the WFD's implementation in the Netherlands. Some interviewees state that the obligation of result only concentrates on taking measures that are planned, and not on attaining the environmental objectives of the WFD. It will be seen below that in most investigated Member States, it is assumed that the good status obligation should be interpreted as an obligation of result rather than an obligation of best efforts and the environmental objectives of the WFD as intervention values rather than target values.

28 Gilissen, Van Kempen and HFMW Van Rijswick, "The Need for International and Regional Transboundary Cooperation in European river basin management as a result of a governance approach in water law' (2009) ERA Forum [online available in 2009, printed version: Springer, 2010/1; HFMW Van Rijswick, 'Interaction between European and Dutch Water Law' in S Reinhard and H Folmer (eds), Water Policy in the Netherlands, Integrated Management in a Densely Populated Delta, Issues in Water Resource Policy (RFF (Resources for the Future) Press, Washington, DC 2009) 213-4. 
Table 2. Transposition and legal qualification of the aim and objectives of the WFD

\begin{tabular}{|c|c|c|c|}
\hline & Transposition & $\begin{array}{l}\text { Legal qualification } \\
\text { of good status } \\
\text { obligation }\end{array}$ & $\begin{array}{l}\text { Legal qualification } \\
\text { of environmental } \\
\text { objectives }\end{array}$ \\
\hline The Netherlands & $\begin{array}{l}\text { Integrated Water Act, } \\
\text { Environmental } \\
\text { Management Act and min- } \\
\text { isterial order }\end{array}$ & $\begin{array}{l}\text { Obligation of best } \\
\text { efforts }\end{array}$ & Target values \\
\hline Luxembourg & Water Act & Obligation of result & Intervention values \\
\hline $\begin{array}{l}\text { Flanders } \\
\text { (Belgium) }\end{array}$ & $\begin{array}{l}\text { Decree on integrated water } \\
\text { policy; to be followed by } \\
\text { ministerial decrees }\end{array}$ & $\begin{array}{l}\text { Probably obligation } \\
\text { of best efforts }\end{array}$ & Intervention values \\
\hline $\begin{array}{l}\text { Wallonia } \\
\text { (Belgium) }\end{array}$ & $\begin{array}{l}\text { Water Act (part of the } \\
\text { Environmental Act) }\end{array}$ & $\begin{array}{l}\text { Obligation of best } \\
\text { efforts }\end{array}$ & Target values \\
\hline Germany & $\begin{array}{l}\text { Federal Water Act and } 16 \\
\text { Länder Water Acts }\end{array}$ & Obligation of result & $\begin{array}{l}\text { Intervention values } \\
\text { (ecological values still } \\
\text { unclear) }\end{array}$ \\
\hline France & Act $2004-318$ & Obligation of result & $\begin{array}{l}\text { Probably intervention } \\
\text { values }\end{array}$ \\
\hline $\begin{array}{l}\text { United Kingdom } \\
\text { (England } \\
\text { and Wales) }\end{array}$ & $\begin{array}{l}\text { Water Environment } \\
\text { Regulations; RBMPs }\end{array}$ & $\begin{array}{l}\text { Probably an } \\
\text { obligation of result }\end{array}$ & $\begin{array}{l}\text { Intervention values } \\
\text { (most) }\end{array}$ \\
\hline Denmark & Water Act & $\begin{array}{l}\text { Probably an } \\
\text { obligation of best } \\
\text { efforts }\end{array}$ & $\begin{array}{l}\text { Probably intervention } \\
\text { values }\end{array}$ \\
\hline Italy & $\begin{array}{l}\text { Act 36/1994 and legislative } \\
\text { decrees 152/1999 and 152/ } \\
2006\end{array}$ & $\begin{array}{l}\text { Probably an } \\
\text { obligation of result }\end{array}$ & Intervention values \\
\hline Romania & $\begin{array}{l}\text { Water Act } 107 / 1996, \text { modified } \\
\text { by Act } 310 / 2004 \text { and Act } \\
112 / 2006 \text { and ministerial } \\
\text { orders }\end{array}$ & $\begin{array}{l}\text { Probably an } \\
\text { obligation of result }\end{array}$ & Intervention values \\
\hline Spain & Amended Water Act & Obligation of result & $\begin{array}{l}\text { Probably intervention } \\
\text { values }\end{array}$ \\
\hline Portugal & Act 58 of 2005 & $\begin{array}{l}\text { Obligation of best } \\
\text { efforts }\end{array}$ & Intervention values \\
\hline
\end{tabular}

It should be noted, however, that the significance of the difference should not be overemphasised in view of the exemptions offered by the WFD. ${ }^{29}$

Perhaps France considers the good status obligation to be an obligation of result and the objectives to be intervention values due to the recent ECJ findings against it for not meeting water quality objectives. ${ }^{30}$ Similarly, Luxembourg may have felt obliged to use these legal qualifications due to the recent finding against it on the implementation of the WFD. ${ }^{31}$ It is not certain

29 See Section 6.

30 Case C-147/07 Commission v France [2008] ECR I-0000. See also: C-239/03 Etang de Berre [2004] ECR I-9325; C-280/02 Commission v France [2004] ECR I-8573; C-130/01 Commission v France [2003] I-5829; C-258/00 Commission v France [2002] ECR I-5959; C-266/99 Commission v France [2001] ECR I-1981.

31 C-32/05 Commission v Luxembourg [2006] ECR I-11323. 
how good status and the objectives are qualified in England and Wales, because the qualification of good status could not be found in the legislation, as the good status obligation had not been transposed into national law. Instead, expert opinion states that it is likely that the United Kingdom will take the view that Article 4 of the WFD contains obligations of result and that the objectives qualify as intervention values. In the Netherlands, legal experts are of the opinion that the good status obligations are obligations of result and would therefore suggest qualifying the environmental objectives as intervention values. ${ }^{32}$ However, the Dutch government takes the view that the good status obligations are obligations of best efforts and therefore the environmental objectives can be qualified as target values. The Danish government takes a similar view with regard to the good status obligations, but the Danish interviewees qualify the objectives as intervention values. The same approach is taken in Portugal, where the objectives are considered as values that should be gradually realised by using reduction percentages. However, a Danish legal expert stated that the environmental objectives from the old water directives were qualified as intervention values as well, but were in practice reduced to being target values. By contrast, in Germany and France both the wording of the text and the interviewees and expert opinion indicated that the good status obligation is considered an obligation of result, but uncertainty persists with regard to the qualification of the environmental objectives as intervention values, in particular with regard to the ecological objectives.

\section{The Use of Exemptions}

It seems that all investigated Member States want to make use of the available exemptions under the WFD. ${ }^{33}$ As stated above, the available exemptions are the extension of the deadlines from 2015 up to 2027, achieving less stringent environmental objectives, and a temporary deterioration or deterioration caused by new developments. It appears that the Netherlands and the United Kingdom (England and Wales) are the most straightforward about using exemptions, as they immediately set the deadline for achieving good status at 2027. While 2015 is considered to be the deadline in the other investigated Member States, it is already foreseeable that it will not be possible to achieve good status in all waters or in all respects and therefore exemptions will be

32 See amongst other things: AAJ de Gier and others, 'The Influence of Environmental Quality Standards and Safety Standards on Spatial Planning, Water and Air as Examples' (2007) 4 J Eur Environ Planning L 23-36; ChW Backes, RL Kruyt and HFMW Van Rijswick, Nieuwe mogelijkheden tot regulering van waterkwaliteitseisen (New Possibilities to Regulate Water Requirements) (Centrum voor Omgevingsrecht en Beleid, Utrecht 2007); HFMW Van Rijswick, Moving Water and the Law, On the Distribution of Water Rights and Water Duties within River Basins in European and DutchWater Law (Europe Law Publishing, Groningen 2008). 
invoked in those Member States as well. The extent to which exemptions will be used can be best discerned at the level of the sub-basins, as it depends on the local circumstances.

For instance, in the German Ruhr river basin district in North Rhine-Westphalia, the use of exemptions is foreseen. In particular the ecologically desirable changes in hydromorphology will require a great deal of time, money and the voluntary cooperation of farmers and therefore meeting that good ecological status or potential will be delayed. One of the reasons for this delay is the difficulty in acquiring land adjacent to the water bodies to create ecological banks. Theoretically, expropriation could be used, but that would destroy the good relations with the agricultural sector. This problem is partly solved by taking a stepping-stone approach. Only river banks in specific areas, which are not too far apart, are changed. These areas should have a positive effect on the whole river basin. In the Danish Odense sub-river basin district the same problem occurs. The Danish authorities have extended the deadline because it would be too expensive to buy land and take restoration measures in the entire river basin district in such a short period of time. They decided that measures cannot be taken everywhere at once and that the restoration of some water bodies will have to wait until the second or third planning period. In the French sub-river basin district of St Brieuc, financial constraints also meant that the expectations as to what could reasonably be achieved before 2015 had to be lowered. In the Netherlands, changing hydromorphology is considered to be too expensive as well. In the case of densely populated areas this seems to be a fairly general problem. Moreover, an agriculturally friendly attitude towards agricultural problems seems to prevail in all the investigated Member States. ${ }^{34}$

It seems that the exemption of delaying the achievement of good status is most popular with the Member States, while lowering the standards is seen as an exemption of last resort to be used if a phased approach has not produced the desired results. The expected costs are used as the main argument for a phased approach. In particular dealing with diffuse, agricultural pollution or achieving the ecological goals concerning hydromorphology is often considered to be time-consuming and expensive. Yet interviewees in all investigated Member States who work at the local level were optimistic about the improvements that will be realised in their river basin district. They consider that achieving good status will depend in particular on finding a successful approach to combat diffuse, agricultural pollution. That would solve both chemical quality concerns relating to pesticide and fertilizer use and ecological concerns related to eutrophication. In 2015, 2021 and 2027 it will be seen

34 This is even the case with the European Court of Justice, HFMW Van Rijswick, 'The Relationship between the Water Framework Directive and other Environmental Directives, With Particular Attention to the Position of Agriculture' (2007) 18 J Water L 193-203. 
which status has been achieved and to what extent it will be necessary to invoke the exemption of lowering the standards.

\section{The No Deterioration Principle}

One of the purposes of the WFD is that the Member States should prevent further deterioration of water bodies. ${ }^{35}$ This purpose is referred to as the no deterioration principle. It is formulated in the WFD more or less in the same wording as the former stand-still principle, according to which the environmental quality of a specific water body may not worsen. The transposition of the no deterioration principle is not formally required, as long as the national legislation implementing the WFD is interpreted in the light of this principle. In all investigated Member States, except the United Kingdom (England and Wales) and Spain, the no deterioration principle had been transposed or was already present in national law. ${ }^{36}$ It is assumed that its meaning closely relates to the stand-still principle. Thus the quality of waters should not deteriorate, unless this can be exempted under the WFD. What does 'no deterioration' refer to? That is the pertinent question here. No deterioration may mean no deterioration at all, but it could also refer to no deterioration between status classes. The WFD mentions different status classes. Concerning chemical status, the status is either good or not good, while ecological status ranges from very good to bad in five different classes. The status of each water body is measured by a number of elements and if one of these elements falls into a lower class, then the 'one out, all out' principle applies, thus lowering the status of the water body.

The no deterioration principle can be further elaborated in (sub-)RBMPs or in the policy of (sub-)river basin management authorities. This involves considering the spatial scale on which deterioration can be observed, the time scale in which deterioration is observed, the scale of seriousness that determines whether deterioration has taken place and the possibility of compensating for deterioration with improvements elsewhere in the (sub-)river basin. It is remarkable that the elaboration of the no deterioration principle did not take place at the national level in legislation in most of the investigated Member States. It seems that Member States prefer to elaborate the principle at the level of the sub-basins. As can be seen in the table below, the uncertainty as to the meaning of the principle is such that in many respects the elaboration of the principle differs considerably.

It should be noted that Luxembourg, Belgium, Italy, Romania, Portugal and Spain are not included in this table, because it is not known how the principle

36 Uitenboogaart and others (n 8) and the questionnaires (n 7). 
Table 3. The 'no deterioration' principle

\begin{tabular}{|c|c|c|c|c|c|}
\hline & $\begin{array}{l}\text { Seriousness of } \\
\text { deterioration }\end{array}$ & Spatial Scale & $\begin{array}{l}\text { Starting } \\
\text { date }\end{array}$ & Time scale & $\begin{array}{l}\text { Compensation } \\
\text { possible? }\end{array}$ \\
\hline $\begin{array}{l}\text { The Netherlands } \\
\text { (Meuse) }\end{array}$ & $\begin{array}{l}\text { Between status } \\
\text { classes }\end{array}$ & Per water body & 2009 & $\begin{array}{l}\text { Six-year } \\
\text { period }\end{array}$ & Yes \\
\hline Germany (Ruhr) & All deterioration & Per water body & 2000 & At all times? & ? \\
\hline $\begin{array}{l}\text { France (Loire- } \\
\text { Brittany) }\end{array}$ & $\begin{array}{l}\text { Between status } \\
\text { classes }\end{array}$ & Per water body & 2009 & $\begin{array}{l}\text { Six-year } \\
\quad \text { period }\end{array}$ & $?$ \\
\hline $\begin{array}{l}\text { United Kingdom } \\
\text { (Anglia) }\end{array}$ & $\begin{array}{l}\text { Between status } \\
\text { classes }\end{array}$ & Per water body & $2006 ?$ & At all times? & No \\
\hline $\begin{array}{l}\text { Denmark (Jutland } \\
\text { and Funen) }\end{array}$ & $\begin{array}{l}\text { Between status } \\
\text { classes }\end{array}$ & Per water body & $\begin{array}{l}2009 / \\
2012\end{array}$ & $\begin{array}{l}\text { Six-year } \\
\text { period }\end{array}$ & In general, no. \\
\hline
\end{tabular}

of no deterioration is further elaborated there in the absence of further research in these Member States at the level of a (sub-)river basin. It is expected that the principle of no deterioration is applied in Flanders (Belgium), because according to the consulted legal expert, no deterioration applies between status classes and all public and private entities in Flanders with competence related to water issues have to take the stand-still principle into account in every stage of decision-making. However, this principle is considered to be an obligation of best efforts. Nothing can be said about its application in Spain, where this principle has not even been transposed. In Italy and Portugal, the principle of no deterioration has been transposed but not further elaborated by the national legislation. In Romania, the principle of no deterioration has also only been transposed into national water legislation. It is considered to have a broad meaning and, as such, to be part of the prevention principle. In Luxembourg, the principle is considered to be a fundamental principle, because the attainment of good status requires at least respect for the principle of no deterioration.

It can be seen in the table above that the practical elaboration differs considerably between the Member States. The spatial scale and the seriousness of deterioration seem obvious; this was elaborated or considered in the same way in all the selected sub-river basins. A German legal expert is of the opinion that deterioration consisted of every negative impact and could therefore also occur within a status class. This approach is also found in a guidance document by DEFRA, ${ }^{37}$ but in East Anglia (United Kingdom) the rule that no deterioration should take place within a status class only applies to parameters relevant to drinking water production in drinking water protected areas. ${ }^{38}$

37 DEFRA is the abbreviation of the UK Department for Environment, Food and Rural Affairs.

38 DEFRA \& WAG (2006), River basin planning guidance, <http://www.defra.gov.uk/ environment/water/wfd/pdf/river-basinguidance.pdf $>$ accessed 20 January 2010. WAG is the abbreviation of the Welsh Assembly Government. 
However, an UKTAG guidance document ${ }^{39}$ stated that it would be a violation of the no deterioration principle if other quality elements deteriorate to the level of the quality element that determined the status of the water body. ${ }^{40}$

Uncertainties persist concerning essential elements. The differences with regard to the time scale are striking. The starting date varies from 2000 to 2012 and while the competent authorities of the investigated sub-river basin districts in Germany (North Rhine-Westphalia) and the United Kingdom (England and Wales) will apparently apply the no deterioration principle at all times, interviewees in France, Denmark and the Netherlands indicated that deterioration was to be observed at the start of each planning period. In Denmark the first planning period may start without observing this principle, as some interviewees in Denmark mentioned 2012 as a starting date, which is when the programmes of measures will become operational. Interviewees in the United Kingdom (England and Wales) did not know from when the no deterioration principle would be observed but indicated that 2006 would be a reasonable starting date, because that was when the monitoring programme started. Interviewees in Germany did not mention any time scale, but said that the principle had applied since the WFD entered into force in 2000.

It appears to be an open question whether compensation is possible. Germany seems to interpret the scale of seriousness most strictly (although this is a topic of discussion in Germany itself), while the Netherlands allows for most flexibility. The Netherlands may be the only Member State which is of the opinion that deterioration in a specific water body can be offset by improvements in other water bodies or the river basin district as a whole. That seems to be in contrast with the widely agreed spatial scale of the principle of no deterioration per water body. However, the Danish Odense RBMP came close to accepting compensation, as it stated that it could be acceptable to allow increased pressure on a water body if that was the only way to prevent an enhanced and serious pollution of another water body. In the United Kingdom, a UKTAG guidance document states that the deterioration of the status of one water body cannot be offset by an improvement in another. ${ }^{41}$

\section{Internal and External Integration}

The WFD does not require integrated water legislation but, rather, integrated water management. According to the ECJ, integrated water legislation can be a very helpful tool to comply with the WFD obligations. ${ }^{42}$ While integrated water legislation may facilitate internal integration (integration within the

39 UKTAG is the abbreviation of United Kingdom Technical Advisory Group.

40 UKTAG ((2006) WP 13e) Prevent Deterioration, <http://www.wfduk.org/tag.guidance> accessed 20 January 2010.

41 Ibid.

42 Case C-32/05 Commission v Luxembourg [2006] ECR I-11323. 
ambit of water law), it leaves the issue of external integration (integration in other policy fields) unanswered. Since the water legislation does not give the competent authorities all the necessary instruments to achieve good water quality, the achievement of the environmental objectives of the WFD will also require action outside the ambit of water management. Therefore, the questions are: what is the legal status of the environmental objectives in other policies? Are the environmental objectives binding for authorities acting outside the ambit of water law? External integration is important to achieve good status, since land use can have a positive or negative impact on water quality. In order to have a good chance of meeting the environmental objectives of the WFD, these objectives should in some way or another have an effect on the implementation of policy fields that concern land use, in particular spatial planning, nature conservation and agriculture. Of course the WFD does not explicitly ask for external integration, because it is up to the Member States how they arrange their environmental legislation. Only the achievement of goals per Member State counts on the EC level.

Before analysing the various integration clauses in the investigated Member States, it is useful to consider the various interpretations of the integration principle. The integration principle is contained in Article 11 TFEU (ex Article 6 EC), which prescribes that environmental protection requirements must be integrated into the definition and implementation of the Union's policies and activities. The integration principle can be interpreted in various ways, which lead to a weak or a strong result. For instance, if the environmental objectives of the WFD are taken into account, this could either mean that they are merely taken into consideration when a decision is taken, or that the authorities are bound by these objectives because they have to be complied with, which entails that they are reflected in the decision and that non-compliance is only permitted when there are good reasons. ${ }^{43}$ Depending on the interpretation of the integration obligation, either the strong or the weak approach occurs with regard to internal and external integration.

It appears from the expert reports that internal integration is widely found within relevant national laws of the investigated Member States. This means that the water authorities have to take water quality norms and standards into account when they make plans and issue permits. It is important to realise (as stated above) that 'taking into account' does not necessarily mean 'comply with'. For example, in Romania, the water authorities may authorize a discharge under specific conditions when the quality of the receiving water exceeds the quality norms. The same appears to apply in Spain, where decisions concerning water may diverge from the water plan as long as there are good reasons for this. In the Netherlands, it is also possible for permits to be

43 See extensively: N Dhondt, Integration of Environmental Protection into Other EC Policies, Legal Theory and Practice (Europa Law Publishing, Groningen 2003) in particular 80-110. 


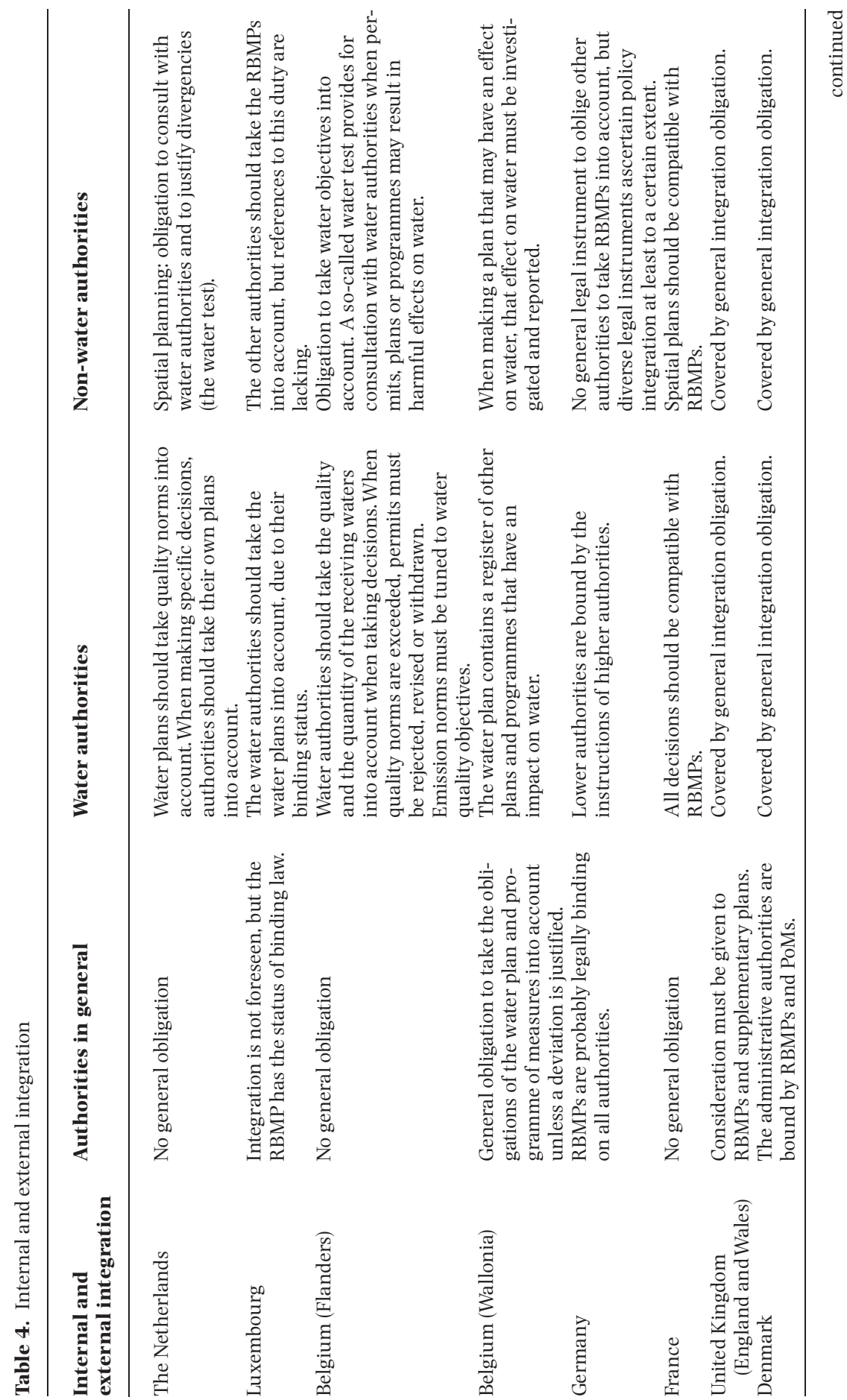




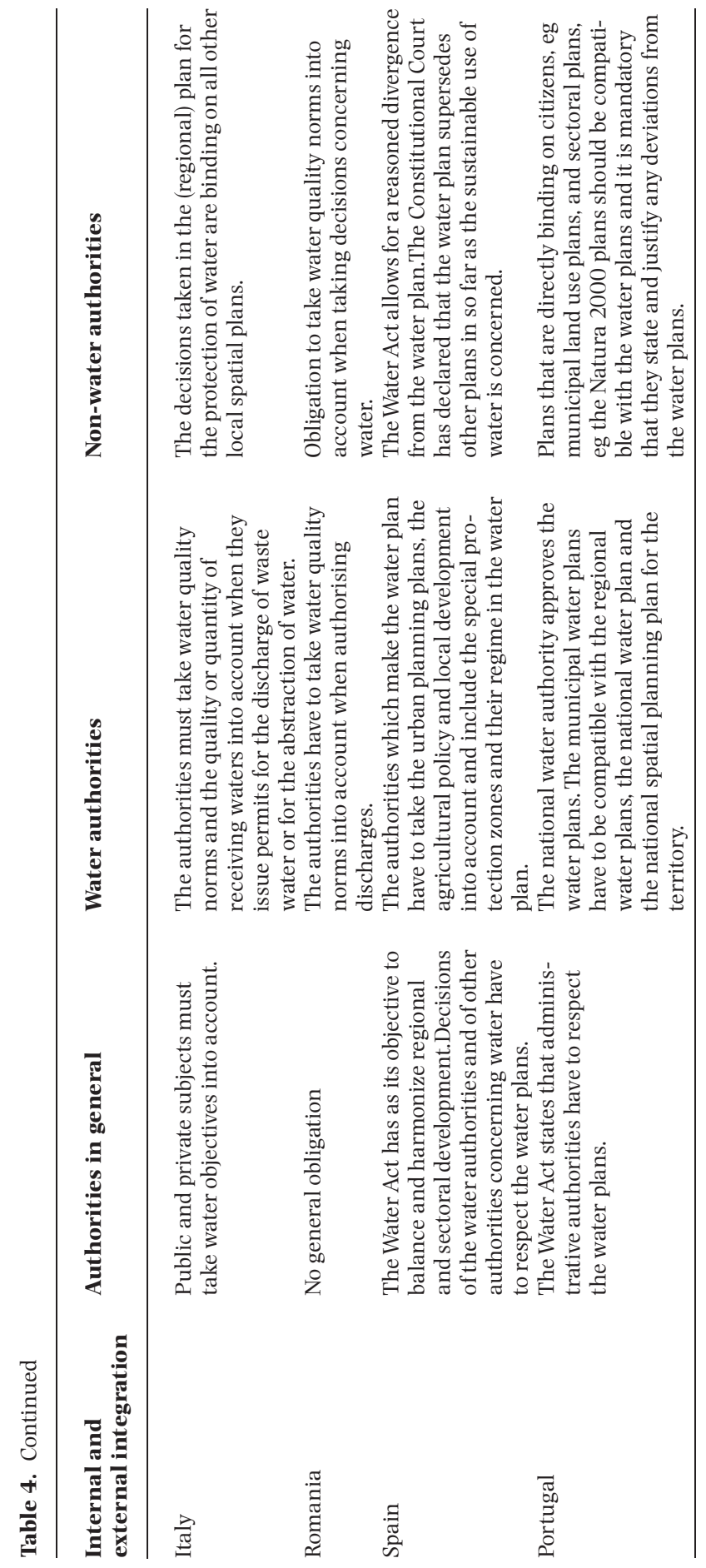


issued even though the receiving water exceeds the quality norms, particularly when the water authorities consider that this can be compensated. According to the Portuguese legal expert, the Portuguese case law has led to a less strict protection regime than could be expected when reading the European and national legislation. Of course it remains to be seen whether the European Court of Justice will condone this practice.

External integration mainly takes place at the level of spatial planning. In general, it appears that water management plans or water quality objectives are required to be taken into account when spatial plans are being drafted in all investigated Member States, except in Spain, where it is the other way around. However, Spanish law in action may present a different picture as the Spanish Constitutional Court has held that the water plans are superior to other plans. In Luxembourg, external integration is not organised in the absence of links between various pieces of legislation. Even though the RBMP is still a draft plan, this is already seen as a problem. Both the Netherlands and Belgium have organised external integration with the introduction of a water test into spatial planning law, which serves to integrate water issues. In Belgium, the water test is also used in other policy areas. It should be noted, however, that in both countries the authorities merely use the water test to address water safety concerns and not to address water quality concerns. ${ }^{44}$

In Italy, the RBMPs bind the other authorities, which are required to ensure that water issues are integrated into other policy areas. Similarly, in France, the spatial plans must be compatible with RBMPs. It should however be noted that in France there is no enforcement when authorities in other policy fields do not comply with water quality standards or ecological goals. In Germany, the question of the binding effect of the management plan was left open in the relevant laws. Legal literature states that the management plan is binding on administrative authorities, but this has no direct effect on the rights and obligations of individuals and compliance with the plan and cannot therefore be enforced by them before the courts. Individuals can however challenge a management plan incidentally - in other words by alleging that an administrative act is unlawful because the management plan on which the act was based is unlawful. ${ }^{45}$ Outside the ambit of spatial planning, the water quality objectives may be taken into account as well; for instance in Romania the Ministry of Administration and Administrative Reform (through its local entities) takes the objectives into account when it promotes processes concerning

44 L Lavrysen and FCMA Michiels (eds), Milieurecht in de Lage Landen, Rechtsvergelijkende Studies Over de Milieuvergunning, Emissiehandel, de Watertoets, Natuurbescherming en Bestuurlijke handhaving in Vlaanderen en Nederland (Environmental Law in the Low Lands, Comparative Legal Studies on the Environmental Permit, Emissions Trading, Water Tests, Nature Conservation and Administrative Enforcement in Flanders and the Netherlands) (Boom juridische uitgevers, The Hague 2004); F Maes and L Lavrysen (eds), Integraal Waterbeleid in Vlaanderen en Nederland (Integral Water Policy in Flanders and the Netherlands) (Die Keure, Bruges 2003) 265-97. 
water infrastructure. Yet it remains to be seen to what extent the water management plans or water quality objectives will be taken into account by other authorities. For this reason it is not possible to establish a link between the qualification of environmental norms and objectives as intervention values or target values and their integration into water policy and other policy areas.

External integration can also take place by cooperation between the various stakeholders. In the Netherlands, cooperation occurs in an informal manner, in the absence of formal cooperation rules. In the Dommel catchment, the Dommel Water Board works with the Municipalities, Provinces and the Inspectorate for Transport, Public Works and Water Management on so-called water programmes for specific regions in the Dommel catchment. These programmes combine land use issues with water management issues-for example nature conservation, adequate water levels for agriculture or flooding measures. The water programmes do not have an official status and participation is voluntary. Other Dutch Water Boards organise the participation of the governmental stakeholders in the implementation of the WFD in another manner. $^{46}$

In Denmark, the external integration of water policy and nature conservation policy is ensured both through a legal link, as both policies are based on the same Act, and through an organisational link. The organisational link is present both in the preparation and in the execution phase. Regional Environmental Centres are responsible for the development of both RBMPs and Natura 2000 management plans, while each municipality has to develop a municipal action plan, which contains the measures that it will take to implement these plans. While many measures will mutually reinforce each other irrespective of whether they are taken for nature conservation or water management, it is also possible for conflicts to arise. For instance, the re-creation of wetlands and the re-establishment of natural hydrology in a certain river valley will retain nutrients and thus reduce eutrophication and create a more natural environment around the river, but it will also threaten the survival of some Natura 2000 habitats and species adapted to the artificial hydrology. This conflict may be avoided by the re-creation of new, similar Natura 2000 habitats to compensate for the flooded habitats. It is however unclear if this is allowed under EC nature conservation law.

It seems that the organisational link in Denmark also has an effect on integration between water, nature conservation and agricultural policy. This became obvious when the 2007 Environmental Permit Law on Livestock Expansion, which aimed to make it easier for municipalities to issue permits to livestock farms for expansion, hardly resulted in expansion. Out of the 2,300 applications submitted in 2007, only 147 permits were in fact granted. Of course this deadlock may be caused by the inability of bureaucracy to 
process the sudden increase in applications, but rejections were often motivated by referrals to the Wadden Sea judgment of the ECJ. ${ }^{47}$ It is assumed that the hesitation of the municipalities is caused by their awareness that they will soon have to start implementing their municipal action plan to meet the objectives set by the Environment Centres in their RBMPs and Natura 2000 management plans. Issuing permits today may mean buying those permits back in the near future in order to be able to meet these objectives. That could be very expensive for the municipalities. It remains to be seen whether the same effects will occur with regard to spatial planning, as the municipalities also have to respect the water and nature policy when they make spatial plans. ${ }^{48}$

The integration of water and agriculture can also take place in water legislation, as the French example shows. Water pollution by nitrates constitutes a serious problem in the French river basin district of Loire-Brittany. In order to reduce nitrate pollution of waters, local authorities can impose the use of fertiliser-free buffer zones by farmers in the sub-RBMP. It should be noted, however, that they can impose buffer zones only for the reduction of nitrates. Of course the imposition of the buffer zones could also be a useful measure to combat pesticide pollution, but there is no legal basis for that in French law and therefore the local authorities cannot impose buffer zones to reduce pesticide pollution in the sub-RBMP. Another complication is that the authorities may impose fertiliser-free buffer zones in the sub-RBMP, but the question is whether they will also enforce their use. It is not a question of competence, as the administrative authorities and the water police have the competence to impose sanctions against individuals in the case of non-compliance with the water legislation, but of political willingness, as the authorities may not want to force farmers to comply with the buffer zones. ${ }^{49}$

In England and Wales (United Kingdom), a general integration provision obliges all authorities to give consideration to the approved RBMPs and any supplementary plan in exercising their functions so far as they affect a river basin district. This has resulted in a link between water and agriculture, which is created both in water policy and in agricultural policy. The RBMPs take the Regional Rural Development Frameworks into account, which are developed by regional organisations under the coordination of regional government offices and contain, amongst other things, the agreed environmental

47 The ECJ strictly applied Art 6 Habitat Directive in Case C-127/02 Waddenvereniging en Vogelbeschermingsvereniging (Wadden Sea) [2004] ECR I-7405. J Verschuuren, 'Effectiveness of the Wild Birds and Habitat Directives in the Wadden Sea Area: Will the Tiger Loose its Teeth?' in Karsten Laursen (ed), Monitoring and Assessment in the Wadden Sea. Proceedings from the 11th Scientific Wadden Sea Symposium (Neri Technical Report, No 573 200, Esbjerg, Denmark 4-8 April 2005) 7-12. Available at: <http://www2.dmu.dk/1_viden/ 2.Publikationer/3 fagrapporter/rapporter/FR 573_Proceeding_Part_1.pdf $>$ accessed 20 January 2010.

48 Uitenboogaart and others (n 8).

49 See above. 
priorities. In addition, the Environmental Agency, working with DEFRA and Natural England (in Wales, respectively, Natural Wales), has set up the Catchment Sensitive Farming programme. This programme offers a range of instruments, including advice and incentives, targeted support in priority catchments and, where required, enhanced regulation. It encourages voluntary action by farmers to tackle diffuse water pollution. By contrast, a specific link is absent between water policy and spatial planning. However, as the English legal expert pointed out, the application of the general integration obligation (which also applies to other relevant European and national legislation, policies and programmes) can be enforced at the central level. Local development schemes must be submitted to the Secretary of State, who has wide powers, including prescribing the form and content of the schemes as well as their approval or rejection. ${ }^{50}$

It becomes clear from the experiences in the investigated Member States that the internal and external integration of the WFD differs widely. This may not come as a surprise in view of the absence of any specific provisions to that effect in the WFD. Furthermore, it is remarkable that interviewees from all investigated Member States are of the opinion that measures taken to comply with ecological objectives of the WFD, such as the restructuring of river banks and the development of ecological zones near river banks, but also a strengthening of the nitrates legislation should be paid for by the government, either by practical measures taken by the government in voluntary cooperation with farmers or by means of compensation or subsidies. This differs strongly from the attitude towards obligations that relate to instruments like environmental licences with emission standards that follow from environmental directives. For instance, stricter emission standards that follow from the IPPC Directive are imposed on the industry without offering compensation schemes.

\section{Conclusions}

In view of the room for divergence left by the WFD, it is not surprising that differences in the legal implementation between the Member States can be discerned. There are differences regarding the qualification of the good status obligations and of the environmental objectives and the way these objectives are integrated into national water and other policies. The research at the level of river basin districts revealed that the elaboration of the no deterioration principle differed considerably as well. It appears that all Member States face WFD implementation problems and consequently it is impossible to say which Member States are the front runners and which Member States are lagging 
behind. The legal implementation of ambitions and ecological goal setting, more in particular the way norms and standards are legally formulated and regulated in national law, the way exemptions are regulated and the legal meaning of the no deterioration principle in the national law of the Member States, do not demonstrate a uniform picture. Moreover, formal legislation does not provide a complete insight into ambitions in practice. That depends also on the available funds, the legal culture in each community, regional problems and solutions, the role of agriculture and so on.

The main differences between the investigated Member States are the following:

- The designation of water bodies does not occur on the basis of the same criteria. While Denmark looks at the best status that a water body can achieve, the Netherlands looks at the initial status irrespective of the status that a water body can achieve.

- While some Member States qualify the good status obligations as obligations of best efforts and the environmental objectives as target values, most Member States qualify them as obligations of result and intervention values. France and Germany seem to be the most strict in this regard, which in the case of France seems to be a consequence of recent ECJ judgments which have gone against it for not meeting water quality objectives.

- All investigated Member States are considering to make use of exemptions in the establishment of a RBMP, in particular to delay the achievement of good status. The Netherlands and the United Kingdom (England and Wales) are the most straightforward about the delay in achieving the good status obligations until 2027. It is expected that other Member States will also resort to invoking this exemption.

- The no deterioration principle may be respected by all investigated Member States, but it is implemented in many different ways, because in general it is only elaborated (if at all) in river basin district management plans. This differentiation concerns important aspects, such as the time from which deterioration is measured and whether deterioration may occur within a class or only between classes.

- Internal and external integration occur in a different manner in all investigated Member States. While internal integration seems rather well ensured, external integration remains problematic. Other authorities are usually not bound by the environmental objectives of the WFD. Denmark has intertwined nature conservation and water policy in one Act and it has made the municipalities responsible for the achievement of good status, which has prompted them to take water quality into account in all other policies they implement. Belgium and the Netherlands have a water test, but use it predominantly to address water safety rather than water quality concerns. 
It must be concluded that the WFD leaves so much room for discretion that the Member States adopt different approaches concerning the implementation of fundamental parts of the Directive. Sometimes their approaches are even complete opposites. Some differences were to be expected given the flexible character of the WFD. Indeed, it is a good thing that European environmental law recognises the great differences in physical circumstances and different water problems in several European river basin districts and places a greater focus on tailor-made solutions. However, different goals and different approaches concerning exemptions, the qualification of waters and the no deterioration principle may give rise to problems further on in the implementation process, particularly when Member States sharing a transnational river basin district disagree on crucial points. Since the WFD is one of the examples in European environmental law of a new approach towards governance, the question arises whether a level playing field in the Member States will be achieved and whether Member States with a low level of ambition can use this new approach to avoid taking the necessary measures, even if these measures already follow from older directives. At the end of the day, this may result in EC water law lacking legitimacy. Especially in transboundary river basins, this may harm the more ambitious Member States.

There is a serious risk that the practical effectiveness of the WFD is at risk, while one of the reasons for choosing a governance approach was to increase effectiveness and legitimacy. We suggest that a flexible governance approach is more appropriate for taking measures than for setting goals and the scope of obligations and concepts. That suggestion leaves the question of how to deal with new ambitions like improving the ecological quality of waters unanswered. A differentiated approach to substances and ecological elements does not however very clearly follow from the Directive itself and certainly not from the European water law system in its entirety. It is for that reason extremely important how the Directive will be explained and enforced by the Commission and the ECJ, not only for the protection of water, but also for further use of a similar governance approach in EC environmental legislation, for example in the field of air quality. When the governance approach merely offers a way out for unambitious Member States, the European Commission and the Court of Justice have a difficult task in avoiding abuse of the discretion which the Member States have due to that approach in the WFD. It will take some years before it becomes clear whether a governance approach leads to abuse and how the Court and the Commission deal with this problem. Only then can it be evaluated whether water quality has improved more under the governance approach offered by the WFD than under the command and control regime of the old water Directives. 